\title{
Moorland landscapes in Switzerland - the changing significance of near-natural cultural landscapes
}

\author{
Marion Leng \& Thomas Hammer
}

Keywords: moorland landscape, cultural landscape, land use, landscape protection, landscape preservation

\section{Abstract}

Switzerland has 89 "moorland landscapes of particular beauty and of national significance". They consist of a large number of natural, near-natural and human-made elements, which entirely determine the character of each individual moorland landscape. They are generally perceived as valuable in terms of ecology, history and aesthetics: they provide habitats for endangered species and for human beings, they bear witness to traditional extensive forms of land use, and they are seen as aesthetically valuable for leisure and recreation. Moorland landscapes are the only constitutionally protected landscape type in Switzerland, but, in spite of the widely accepted aim to protect them, they are by no means secure. Conflicting trends, such as the intensification of land use, the abandonment of agricultural land and the growth in outdoor sports, mean that the biodiversity, unique character and variety of some of the remaining moorland landscapes are threatened. They can only be preserved if extensive land use, adapted to the special conditions in moorland landscapes, and associated maintenance measures continue and unsuitable forms of land use and over-use are avoided.

\section{Introduction}

The problematic situation described above provided the starting point for this research project as part of the Swiss involvement in European cooperation in the area of scientific and technological research, the COST Action A27 Understanding Pre-Industrial Structures in Rural and Mining Landscapes (LANDMARKS). The aim of the project is to identify and describe the many aspects of the changing human significance of moorland landscapes in order to identify and document associated changes in landscape. Results of this project are presented in Hammer, Egli \& Atmanagara 2008, Hammer \& Leng 2008, Hammer, Leng \& Raemy, accepted.

\section{Multifunctional landscapes}

The Swiss view of a moorland landscape as a nearnatural cultural landscape is a unique expression of a holistic perception of the combination of natural, near-natural and cultural elements. Swiss moorland landscapes are important to society in many ways, ranging from the material to the non-material and geo-ecological aspects of their significance (Hammer \& Leng 2008).

The material significance is associated with the satisfaction of physical human needs. In their indirect material significance, they serve as settlement areas and locations for infrastructure. The direct material significance rests mainly in the function of moorland landscapes for farming and peat harvesting.

The non-material significance of moorland landscapes is related to mental well-being: they serve as sources of inspiration and knowledge and also play an important emotional and aesthetic role.

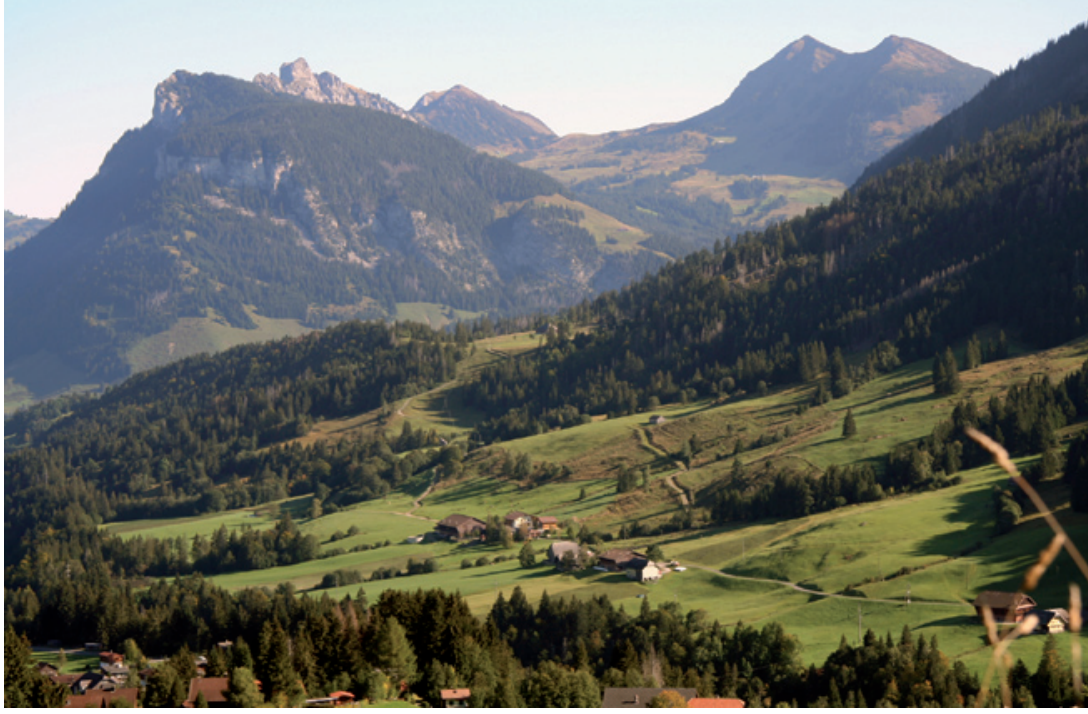

Landscape section Hagleren of the national protected moorland landscape Glaubenberg in UNESCO Biosphere Reserve Entlebuch (UBE): the moorland areas are the major landscape feature of the UBE and at the same time a cultural landscape of diverse structures. Its ecological values emerged through gentle forms of land use and forestry

In addition to the material and non-material significances, moorland landscapes work as regulators of natural processes and regulate the effects of human interventions in natural processes (geo-ecological significance).

\section{Material significance}

Indirect material significance

Especially in times of economic and political crisis, moors and moorland landscapes have been used as settlement areas and locations for infrastructure. Major motives included seeking shelter from intruders and meeting the increasing demand for space and food of a growing population. 


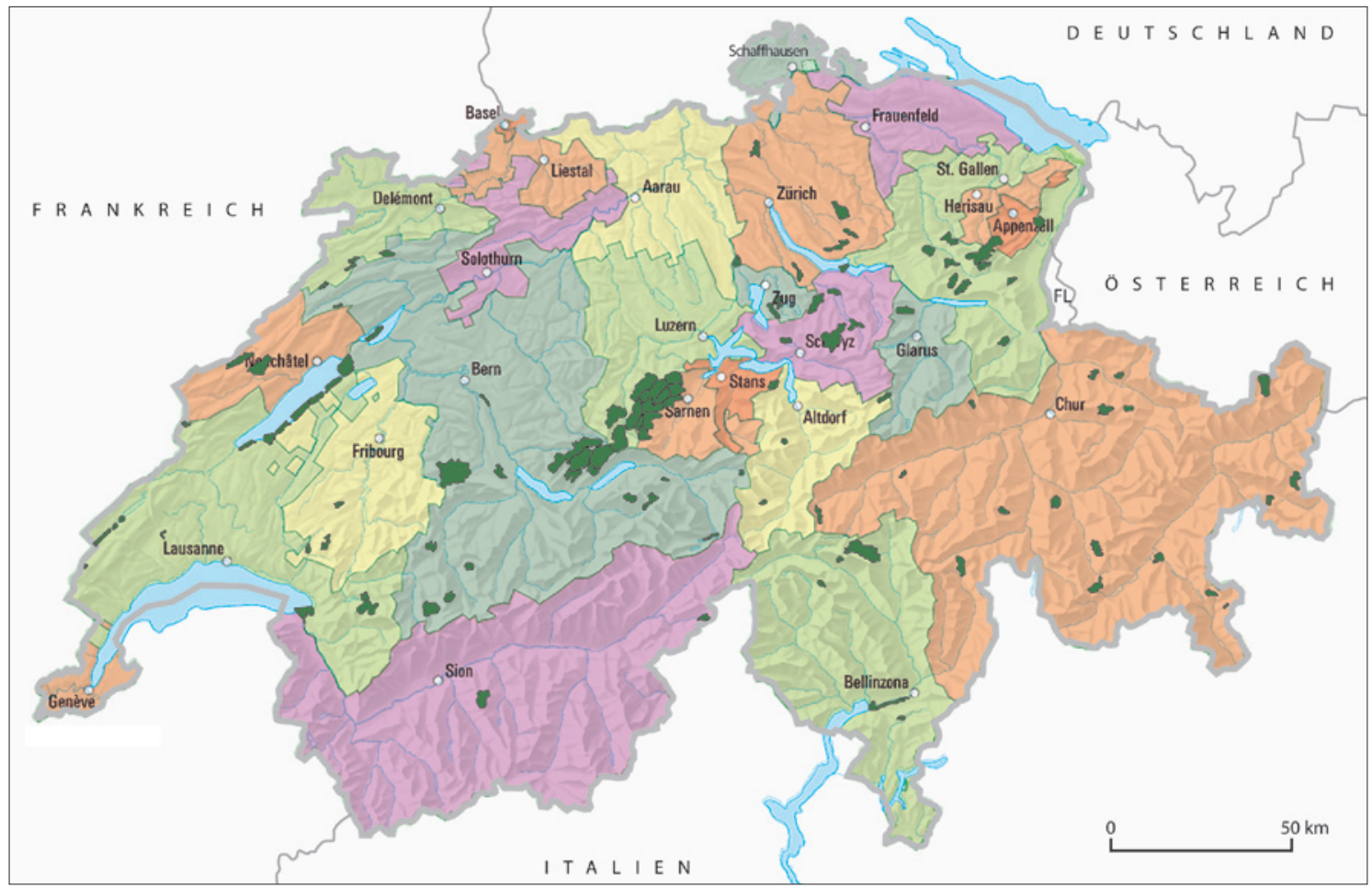

Figure 1 - The 89 moorland landscapes of particular beauty and national significance in Switzerland. geodata (C) swisstopo. Source: http:/ / wmw.ecogis.admin.ch, adapted by R. Tillmann

Due to their dispersed occurrence, their peripheral location and their low agricultural productivity, moorland landscapes often were, and parts of some still are, used for military purposes.

\section{Direct material significance}

The direct material uses, such as farming and peat harvesting, had a greater influence on the change of moorland landscapes than the indirect material uses. The agricultural use of moorland landscapes, especially as pastures and litter meadows, caused the creation of wide areas with fens. Nowadays a lot of fens are threatened by incipient scrub and forest encroachment as a result of under-use. Bogs too were used for agricultural purposes. In contrast to fens, the agricultural use of bogs limited their functionality or ruined them completely. Another reason for the destruction of bogs was the harvesting of peat for fuel. Especially in times of need and until the spread of mineral oil products in the $20^{\text {th }}$ century, peat was an important alternative to wood and coal. During the Second World War, the harvesting of peat was subsidized in Switzerland. As a result, many bogs were destroyed. Some parts of the moorland landscapes changed greatly because of partial or complete harvesting.

\section{Non-material significance}

Sources of inspiration and knowledge

In their non-material significance, moorland landscapes serve as sources of inspiration and knowledge (e.g. literature, art, research).
For a long time, moors and moorland landscapes were described as places of uneasiness, horror, crime and death in literary and artistic works. One of the great exceptions from the negative descriptions of moors and moorland landscapes until the end of the $19^{\text {th }}$ century is the work of the artists' colonies. Their paintings of the meetings of humans with nature express a kind of idyll and thereby a new perception of moorland landscapes. They contributed greatly to a higher societal appreciation of moors and moorland landscapes.

Apart from their literary and artistic significance, moors and moorland landscapes also increase the level of knowledge in science. Moor archaeology with its specific methods, for example, promotes the increase of knowledge in different disciplines and fields of research. As archives of the history of nature, landscapes and culture, moors and moorland landscapes conserve a large variety of objects, ranging from pollen to human remains.

The emotional and aesthetic role

While the direct material uses are declining, the aesthetic significance and the emotional appreciation of moorland landscapes are steadily increasing. This became obvious in the acceptance of the "Rothenthurm-Initiative" in 1987, which led to the protection of "moorland landscapes of particular beauty and of national significance".

The moorland landscape of Rothenthurm (cantons Schwyz and Zug) is characterized by a variety of fens and bogs. The Biber brook meanders between the moors. Typical floodplain vegetation and pioneer plants such as birches grow along its edges. One of the 
best-known aspects is the seasonally changing variety of colours in the landscape, produced mostly by the different shades of auburn of the litter meadows. The appreciation of the moorland landscapes as beautiful landscapes was of great importance during the referendum and essential for the acceptance of the initiative. Personal non-material enrichment, based on sensual perception and aesthetic pleasure, becomes more and more evident in the context of sporting activities and tourist uses. The significance of moorland landscapes for recreation and leisure has increased steadily in recent decades.

\section{The geo-ecological function}

Moors and moorland landscapes reproduce a particular flora and fauna and are characterized by specific ecosystems. They contribute to the regulation of the water balance, the balance of matter, the climate and to the absorption of pollutants. They store carbon and absorb $\mathrm{CO}_{2}$.

The role of moors becomes ever more important, particularly in the debate about climate change: globally, they store about twice as much carbon as the biomass of all forests put together. This amounts to more than one third of the worldwide terrestrial carbon. As the most important long-term storage for organic carbon on the surface, moors represent a natural $\mathrm{CO}_{2} \operatorname{sink}$ which each year binds enormous amounts of $\mathrm{CO}_{2}$ in the form of peat. These geo-ecological functions of moors and moorland landscapes are increasingly appreciated.

\section{Protection and preservation}

The protection of moors in Switzerland can be traced back to at least the beginning of the $20^{\text {th }}$ century. The institutionalization at national level, however, could only be effected as a result of the conflict over a military project in the 1980 s, which was planned to be realized in the moors of Rothenthurm.

These conflicts between the military and conservationists as well as anti-military activists led to the launch of an initiative which demanded the protection of moors and of the whole moorland landscapes. In 1987, the initiative was accepted and the protection of moors and moorland landscapes was enshrined in the constitution. In addition, the Swiss Nature and Cultural Heritage Protection Act and the decree on Swiss Nature and Cultural Heritage Protection were amended. Three new decrees were created, for bogs and transitional moors, for fens and for moorland landscapes. Presently, 89 moorland landscapes, about 3300 fens and 549 bogs are protected at national level.

National regulations are inadequate for implementing the conservation objectives for the moorland landscapes. The three political-administrative levels in Switzerland - federal, cantonal and communal - share the responsibility for realizing the overall objective ("multi-level protection of moorland landscape"). To

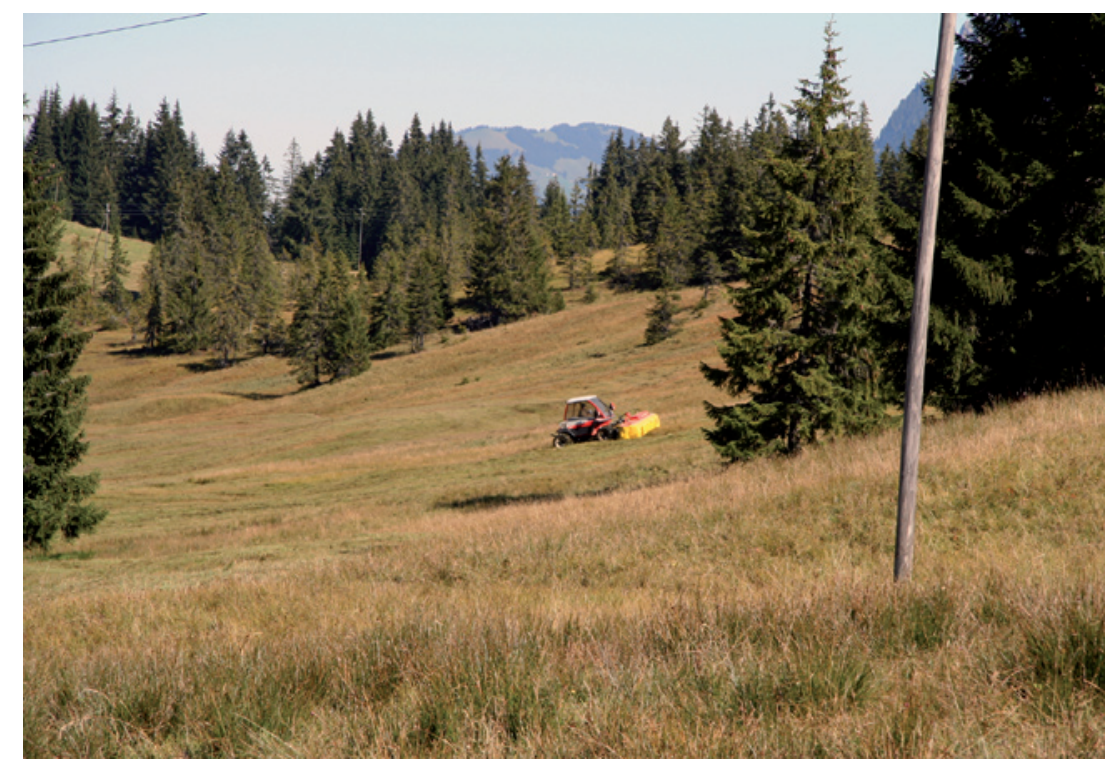

Extensive agricultural use of low-moor bogs in the moorland area Habkern / Sörenberg in the UBE: in addition to traditional forms of use as pastures, gentle modern forms of use such as mechanical litter cutting are permitted to maintain the diversity of the moorland landscapes

achieve this, they have to coordinate their actions, these must complement each other and must be coherent. The legislative responsibility for the implementation of the Rothenthurm initiative lies with the federal level. The cantons represent the interests of the communities and are responsible for enforcing federal laws. At local level, the communities transfer the regulations for use and protection into their utilization planning ("Nutzungsplanung"). These plans are legally binding for the landowners who are compensated for any loss of income caused by the regulations. The interests of the communities can be represented by regional planning associations, which can negotiate with the state and produce directive regional plans. These have to be approved by the canton. In Switzerland the regulations to protect moorland landscapes are thus formulated at federal level, passed on to the cantonal level for implementation and institutionalized in utilization planning at communal level. Adequate planning of use and protection for the moorland landscapes is a result of cooperation between canton, communities and landowners.

\section{Conclusion}

About 20 years after the acceptance of the initiative and in spite of manifold efforts, the aims concerning the protection of moors and moorland landscapes have not or at least not entirely been achieved.

The ecological quality of many nationally protected moors is deteriorating and the area of intact bogs is decreasing. Incipient scrub and forest encroachment is on the increase. Moorland landscapes change slowly but steadily, due to the combined effect of many creeping changes which threaten the specific character of the moorland landscapes. 
The growing significance of the moorland landscapes for humans, the appreciation of the non-material aspects and the identification of newly important features reflect the changes that have occurred in the relationship of humans with nature. Nowadays, moorland landscapes are perceived as ecologically, historically and aesthetically valuable, near-natural, cultural landscapes. The challenge for management now is to avoid creeping changes and to preserve the diverse assets of these landscapes.

The manifold changes in the significance of moorland landscapes for humans provide starting points for the preservation and further development of moorland landscapes, applying new, extensive forms of land use. New and non-material aspects (especially aesthetic value, leisure und recreation) are gaining in significance. They have become central arguments for the conservation of moorland landscapes and are increasingly used within the local economy. Agritourism, educational tourism and wellness facilities as well as high-quality local produce can have a positive effect on local social and economic value creation, such as new jobs in the tourist industry (Hammer \& Leng 2008, Hammer, Leng \& Raemy, accepted), and should be integrated in the management concepts for moorland landscapes.

\section{References}

Hammer, T., H.-R. Egli \& J. Atmanagara 2008. Cultural Landscape in Conflict between Economy, Ecology, and Institutional Steering. The Example of the UNESCO Biosphere Entlebuch (Switzerland). In: C. Bartels, M. Ruiz Des Arbol, H. van Londen \& A. Orejas (eds.), Landmarks. Profiling Europe's Historic Landscapes: 99-112. Bochum.

Hammer, T. \& M. Leng 2008. Moorlandschaften im Bedeutungswandel. Zur gesamt-gesellschaftlichen Aufwertung naturnaher Kulturlandschaften. In: Allgemeine Ökologie zur Diskussion gestellt (10). Schriftenreihe der Interfakultären Koordinationsstelle für Allgemeine Ökologie (IKAÖ). Bern.

Hammer, T., M. Leng \& D. Raemy (accepted). Swiss Moorland Landscapes and the Significance of Economic and Technological Change. Origins, Threats and new Patterns of Use. In: L. LÉVÊQQUE et al. (eds., 2009 in print), Heritage, Images, Memory of European Landscapes.

\section{Authors}

\section{Marion Leng}

Forest scientist, historian and Romance language specialist; research scientist. Marion Leng (born 1970) studied history and French at the Heinrich Heine University in Düsseldorf to MA level and obtained a first level teaching degree. After finishing a bachelor degree in forestry science and forest ecology at the Georg August University in Göttingen, her doctoral thesis dealt with education for sustainable develop- ment in European large protected areas and presented the scope and limits of education concepts. She heads the university's continued studies course in sustainable development (Certificate of Advanced Studies Nachhaltige Entwicklung, CAS NE). Her research focuses on landscape development and education for sustainable development.

leng@ikaoe.unibe.ch

\section{Thomas Hammer}

Geographer, senior lecturer. Thomas Hammer (born 1962) studied geography (major), history, economics and informatics at the University of Freiburg $(\mathrm{CH})$. After obtaining a teaching degree in geography, he was a lecturer at the Research Institute of Economic Geography and Regional Policy at the University of St.Gallen (HSG). His doctoral thesis focused on rural development strategies in Burkina Faso. The theme of his post-doc Habilitation is sustainable development in the West-African Sahel states. He heads several research projects on issues of regional and landscape development. His research focuses on sustainable regional, landscape and large protected area development as well as on desertification and the fight against desertification.

hammer@ikaoe.unibe.ch

Interfakultäre Koordinationsstelle für Allgemeine Ökologie (IKAÖ)

University of Bern

Schanzeneckstr. 1

Postbox 8573

3001 Bern

All photographs (C) Thomas Hammer 